\title{
THE EFFECT OF PERCEIVED BENEFITS AND PERCEIVED RISKS ON INTENTION TO SHOP APPAREL ONLINE BY WHITE - COLLAR WOMEN IN VIETNAM
}

\author{
HOANG THI PHUONG THAO \\ Ho Chi Minh City Open University, Vietnam - Email: thao.htp@ou.edu.vn \\ NGUYEN NGOC THANH HAI \\ Ho Chi Minh City Open University, Vietnam - Email: nguyenngoc.thanhhai@gmail.com \\ (Received: June 14, 2016; Revised: July 4, 2016; Accepted: October 10, 2016)
}

\begin{abstract}
Online apparel shopping has become more and more popular and has attracted many consumers. This research aims to study how these perceived benefits and perceived risks influenced Internet users on buying apparel online. A survey of 298 white-collar women was carried out to identify the benefits and risks when buying apparel online. Five dimensions of perceived benefits (i.e. convenience shopping, abundance and liking product, competitive price, enjoyment, and comfortable shopping) and three dimensions of perceived risks (i.e. financial risk, product risk, and time risk) were ascertained by exploratory factor analysis. The correlation between these benefits and risks with online purchasing intention was explored by multiple regression tests. The result demonstrates that consumers perceive benefits more than risks in online apparel shopping. While 'comfortable shopping' has the strongest effect on respondents' intention, 'competitive price' has the lowest effect. Among the risks, product risk is of highest concern, followed by financial risk and time risk. The result also shows that middle-age white-collar women of 31 to 40 years old have the intention to shop apparel online higher than other groups.
\end{abstract}

Keywords: Perceived benefits; perceived risks; online apparel shopping.

\section{Introduction}

Internet has become a platform in developing applications and has changed not only business methods but also people's communication manners. It offers consumers a wide range of products and services. They can buy or sell anything, at any time, and from anywhere through e-commerce system (King et al., 2008). Specially, online apparel with abundant types, unique and rare designs, has provided customers with a lot of information about products and competitive prices (Javadi et al, 2012). By that way, online apparel websites prove to be more advantageous than traditional stores.

However, it is perceived that risks and mistrust in virtual stores are higher than in traditional ones, especially security and privacy risks (Martin and Camarero, 2009). Consumers often worry that what they receive will not be as good as what described in the web. Despite those risks, the number of online shoppers has been increasing. The number of Vietnamese online-shoppers increased from $68.4 \%$ to $80.2 \%$ in 2015, reaching the second growth rate in the Asia Pacific (The Saigon Times, 2015). This proves that consumers perceive significant benefits of this shopping type; for example, they can shop from home and at any time. According to a report by Vecita (2014), $58 \%$ of Internet users have purchased items online, of which the most popular products belong to apparel and accessories (taking up $60 \%$ of online shoppers).

Aiming to provide apparel website owners with more information to improve their business, this study conducts an analysis of dimensions of consumers' perceived benefits 
and risks and their effects on apparel shopping intention of Vietnamese white-collar women.

\section{Literature review}

\section{Shopping intention}

Shopping Intention is an important figure for monitoring and mearsuring in advertisement and marketing because brands want to spend money attracting market audience to use their product or service (Crespo, 2009). It is an anxious expression for buying a product or service in the future. Shopping intention is determined as a plan purchase products or services in the future from consumers who have not purchased that type of products or services yet (Martin and Camarero, 2009).

Frosythe's research (2006) proved that consumers who purchased online frequently and spent a lot of money for this channel perceived more benefits than risks. While Wani and Malik (2013) noted that consumers perceived risks higher than perceived benefits, especially in India. Therefore, it is interesting to find out what kinds of benefits and risks of online shopping the Vietnamese consumers concern most.

\section{Perceived benefits}

Benefit is a convenience or profit achieved from anything. Perceived benefit is a trust about positive result in reality or when under a threat (Oxford, 1089). Lim's and Ting's research (2012) showed that perceptions have affected significantly to attitude and online shopping intention of individuals. Online shopping helps consumers to save time and so it attracts consumers (Alreck and Settle, 2002). Internet users in Malaysia agreed that online shopping brings many benefits as money saving, convenience, cheaper price, accessibility to information and 24/7 service (Azura, 2010). Consumers' perceived benefits were highly related to their attitudes toward online shopping. They are all the advantages and satisfactions which consumers need and want when purchasing online. Consumers usually compare benefits among shopping channels and what motivate them most to do online shopping was its convenience (Delafrooz and Narges, 2009). A study conducted by Nguyen Thi Bao Chau and Le Nguyen Xuan Dao (2013) also showed that convenience was the main reason for consumers to start or continue to shop online. Competitive price was another important reason for online shopping. Chan (2012) examined the relationship between perceived benefits and online shopping decisions made by Malaysian students. Product quality and convenience are two main factors mostly affected their decisions. In the context of apparel shopping, perceived benefits include the following dimensions - convenience shopping, abundance and liking product, comfortable shopping, enjoyment and competitive price.

\section{Perceived risks}

Grahame and Rischard (1994) defined that risk was perceived as uncertain and bad consequences when taking part in an activity. Perceived risk also means consumers' ability to continue to follow the process consequence which they expected when shopping online. Perceived risk reduces consumers' intent to purchase online (Barnes, 2007).

Online shopping could lead to negative consequences which did not appear in traditional shopping. For example, consumers cannot directly test the product quality or communicate with the sellers and must learn how to use Internet and search for websites beforehand. To shift to e-commerce channel might be a little stressful for consumers who are uncomfortable with using Internet and make them feel unsecured when their payment and private information are disclosed. Perceived risks made consumers unwilling to reveal information about their individual payment card when doing online transactions (Hoffman, 1999). Whatever the case, consumers will have to consider many different signals based on their own perceived risks to build a positive attitude and perception toward websites (Martin and Camarero, 2009). Javadi (2012) stated that 
online shopping risks had significant impacts on consumers' online shopping behaviors. The main risks include financial risk and nondelivery risk (Wani and Malik, 2013). Consumers must pay cost and handling charges (financial risk) and must wait until the goods are delivered (time risk). There is also a product risk that customers may not receive the product after making online payment or may not receive the same thing as what they saw on the website. This study proposed three dimensions of perceived risks: financial risk, product risk, and time risk.

\section{Developing hypotheses}

As described in the above literature review, the perceived benefits are represented by 5 independent variables - convenience shopping, abundance and liking product, competitive price, comfortable shopping, and enjoyment while the perceived risks are represented by 3 independent variables financial risk, product risk, and time risk. One dependent variable is the intention to do online apparel shopping by white-collar women. They are defined in Table 1.

\section{Table 1}

Definition of variables

\begin{tabular}{|l|l|}
\hline \multicolumn{1}{|c|}{ Dimension } & \multicolumn{1}{c|}{ Definition } \\
\hline Sonvenience & Transactions will be carried out without difficulties. \\
\hline $\begin{array}{l}\text { Abundance and } \\
\text { Liking Product }\end{array}$ & $\begin{array}{l}\text { Abundance apparel mentions a large range of quantities and diversity. } \\
\text { Liking is consumers' priority to choose certain apparels over others. }\end{array}$ \\
\hline Competitive Price & Best price which consumers must pay for the apparel they chose. \\
\hline $\begin{array}{l}\text { Comfortable } \\
\text { Shopping }\end{array}$ & Consumers' assurance and relaxation when purchasing apparel online. \\
\hline Enjoyment & Consumers' happiness and pleasure when shopping apparel online. \\
\hline Financial Risk & $\begin{array}{l}\text { The potential monetary outlay associated with the initial purchase price } \\
\text { as well as the subsequent maintenance cost of the apparel and the } \\
\text { potential financial loss due to fraud. }\end{array}$ \\
\hline Time Risk & $\begin{array}{l}\text { Potential loss of time associated with making a bad purchasing decision by } \\
\text { wasting time researching, shopping, or having to replace the unexpected } \\
\text { apparels. }\end{array}$ \\
\hline $\begin{array}{l}\text { Product Risk } \\
\text { The possibility of the apparel malfunctioning and not performing as it was } \\
\text { designed and advertised and therefore failing to deliver the desired } \\
\text { benefits. }\end{array}$ \\
\hline $\begin{array}{l}\text { The plan that white-collar women will purchase apparel online in the } \\
\text { white-collar women } \\
\text { near future. }\end{array}$ \\
\hline
\end{tabular}

From the above description of dependent and independent variables, the following research hypotheses are proposed:

H1: The perceived convenience shopping has a positive influence on intention to shop apparel online of white-collar worker women.

$\mathrm{H} 2$ : The perceived abundance and liking product has a positive influence on intention to shop apparel online of white-collar worker women. 
H3: The perceived competitive price has a positive influence on intention to shop apparel online of white-collar worker women.

$\mathrm{H} 4$ : The perceived comfortable shopping has a positive influence on intention to shop apparel online of white-collar worker women.

H5: The perceived enjoyment has a positive influence on intention to shop apparel online of white-collar worker women.

H6: The perceived financial risk has a negative influence on intention to shop apparel online of white-collar worker women.

H7: The perceived time risk has a negative influence on intention to shop apparel online of white-collar worker women.

H8: The perceived product risk has a negative influence on intention to shop apparel online of white-collar worker women.

\section{Research approach}

Formation of questionnaire

Based on the related literatures and our previous studies, we designed a questionnaire. Firstly, we summarized all items about perceived benefits and risks and online shopping behaviors in the previous studies. Then, after discussing with eight owners of apparel online websites, we reworded some items to make them more understandable and suitable to the study. We also added and combined 07 items, and erased 11 items.

Finally, we came up with the formal questionnaire, of which 36 measurement items were listed in part 1 to measure dimensions of the benefits (20 items) and risks (16 items), and 04 items of part 2 were used to measure intention to shop apparel online by whitecollar women. A 5-point Likert scale (from strongly disagree to strongly agree) was used to indicate the level of agreement to each item selected by the respondents.

\section{Sample description}

The data collection was conducted through a personal survey of Internet users in October, 2015. The convenience sampling was utilized to approach respondents. The subjects include white-collar women from 22 to 50 years of age, who had not purchased apparel online yet. More than 350 questionnaires were distributed to respondents and 298 usable feedbacks were selected for further analysis. Table 2 shows that all respondents understand about Internet and online shopping, most of them are at their middle age (31-40 years old) with monthly income ranging from VND5 million to VND10 million.

\section{Table 2}

Demographic characteristics of sample

\begin{tabular}{|l|c|c|c|}
\hline \multicolumn{1}{|c|}{ Measure } & Item & Frequency & Percentage \\
\hline Daily access to Internet (hour) & $<2$ & 0 & 0 \\
& $2-4$ & 51 & 17.1 \\
& $5-6$ & 69 & 23.2 \\
& $>6$ & 178 & 59.7 \\
\hline Monthly access to E-commerce & 0 & 5 & 1.7 \\
(nearest 3 months) & $1-3$ & 212 & 71.1 \\
& $4-6$ & 81 & 27.2 \\
\hline Age & $22-30$ & 98 & 32.9 \\
& $31-40$ & 136 & 45.6 \\
& $41-50$ & 64 & 21.5 \\
\hline Monthly income (VND) & $<5,000,000$ & 31 & 10.4 \\
& $5,000,000-10,000,000$ & 153 & 51.3 \\
& $>10,000,000-18,000,000$ & 85 & 28.5 \\
\hline
\end{tabular}




\section{Data analysis and results}

Reliability analysis

Nine constructs with 39 items are entered to analyze their reliability of measurement. After testing Cronbach's Alpha reliability, the result showed that Corrected Item-Total Correlation of items PROD_05 (I may find rarely unique apparel in the web), PRIC-09 (I see apparel's price in web store is cheaper than those in physical store), ENJY-16 (Purchasing apparel online is new experience that makes me exciting) less than 0.3 so three items were deleted. Thus, 36 items were used for further exploratory factor analysis. The result of reliability test is showed on Table 3.

Table 3

Cronbach's Alpha Reliability Analysis

\begin{tabular}{|c|c|c|c|c|c|}
\hline Dimension & Code Item & Item Statement & Mean & $\begin{array}{l}\text { Std. } \\
\text { Deviation }\end{array}$ & $\begin{array}{c}\text { Cronbach's } \\
\text { Alpha if } \\
\text { deleted item }\end{array}$ \\
\hline \multirow{5}{*}{ 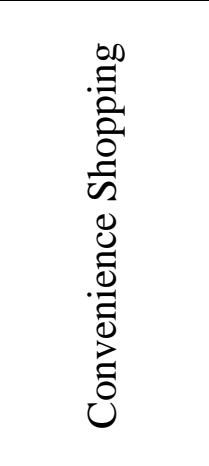 } & CONV_01 & $\begin{array}{l}\text { Online apparel shopping is at } \\
\text { anywhere. }\end{array}$ & 3.91 & 0.760 & 0.635 \\
\hline & CONV_02 & $\begin{array}{l}\text { Online apparel shopping is at } \\
\text { any time. }\end{array}$ & 3.81 & 0.793 & 0.600 \\
\hline & CONV_03 & $\begin{array}{l}\text { I don't need to be hurry when } \\
\text { shopping online. }\end{array}$ & 3.31 & 0.878 & 0.635 \\
\hline & CONV_04 & I don't need to wait for paying. & 3.42 & 0.930 & 0.629 \\
\hline & \multicolumn{5}{|c|}{ Cronbach's Alpha: $0.689 \quad$ Overall mean: 3.610} \\
\hline \multirow{4}{*}{ 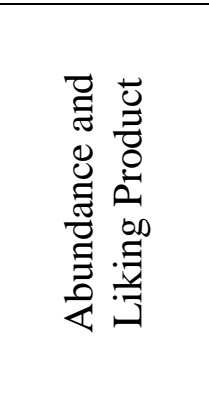 } & PROD_06 & $\begin{array}{l}\text { Buyers may design apparel that } \\
\text { suits their hobby. }\end{array}$ & 3.88 & 0.869 & 0.759 \\
\hline & PROD_07 & $\begin{array}{l}\text { I may have full information } \\
\text { about apparel on website. }\end{array}$ & 3.83 & 0.888 & 0.562 \\
\hline & PROD_08 & $\begin{array}{l}\text { I may find apparel that suits my } \\
\text { hobby from all over the world. }\end{array}$ & 3.80 & 0.944 & 0.606 \\
\hline & \multicolumn{5}{|c|}{ Cronbach's Alpha: $0.735 \quad$ Overall mean: 3.833} \\
\hline \multirow{4}{*}{$\begin{array}{l}0 \\
: \\
0 \\
0 \\
0 \\
: 0 \\
0 \\
0 \\
0 \\
0 \\
0\end{array}$} & PRIC_10 & $\begin{array}{l}\text { Sale programs on website will } \\
\text { help me to save money. }\end{array}$ & 3.54 & 0.652 & 0.642 \\
\hline & PRIC_11 & $\begin{array}{l}\text { It is easy to compare prices } \\
\text { online. }\end{array}$ & 3.71 & 0.693 & 0.642 \\
\hline & PRIC_12 & $\begin{array}{l}\text { It is easy to find the best price } \\
\text { before purchasing. }\end{array}$ & 3.34 & 0.768 & 0.593 \\
\hline & \multicolumn{5}{|c|}{ Cronbach's Alpha: $0.716 \quad$ Overall mean: 3.531} \\
\hline \multirow{3}{*}{ 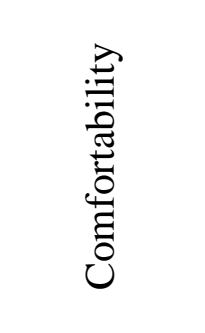 } & COMF_133 & $\begin{array}{l}\text { I don't feel nervous or shy if I } \\
\text { just do window shopping. }\end{array}$ & 3.39 & 0.740 & 0.586 \\
\hline & COMF_14 & $\begin{array}{l}\text { Website interface will help me } \\
\text { easy to search and transact. }\end{array}$ & 3.70 & 0.668 & 0.593 \\
\hline & COMF_15 & $\begin{array}{l}\text { I don't need to wait for service } \\
\text { staff. }\end{array}$ & 3.49 & 0.922 & 0.616 \\
\hline
\end{tabular}




\begin{tabular}{|c|c|c|c|c|c|}
\hline Dimension & Code Item & Item Statement & Mean & $\begin{array}{l}\text { Std. } \\
\text { Deviation }\end{array}$ & $\begin{array}{l}\text { Cronbach's } \\
\text { Alpha if } \\
\text { deleted item }\end{array}$ \\
\hline & \multicolumn{5}{|c|}{ Cronbach's Alpha: 0.668 Overall mean: 3.430} \\
\hline \multirow{4}{*}{ 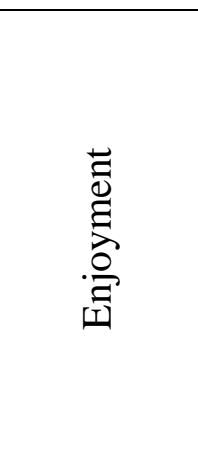 } & ENJY_17 & $\begin{array}{l}\text { I may feel excited when } \\
\text { receiving package of apparel } \\
\text { shopped online. }\end{array}$ & 3.06 & 0.837 & 0.562 \\
\hline & ENJY_18 & $\begin{array}{l}\text { I am attracted by beautiful } \\
\text { apparel images on website. }\end{array}$ & 3.19 & 0.951 & 0.451 \\
\hline & ENJY_19 & $\begin{array}{l}\text { Online apparel shopping will } \\
\text { make me feel happy. }\end{array}$ & 3.12 & 0.895 & 0.586 \\
\hline & \multicolumn{5}{|c|}{ Cronbach's Alpha: $0.636 \quad$ Overall means: 3.124} \\
\hline \multirow{6}{*}{ 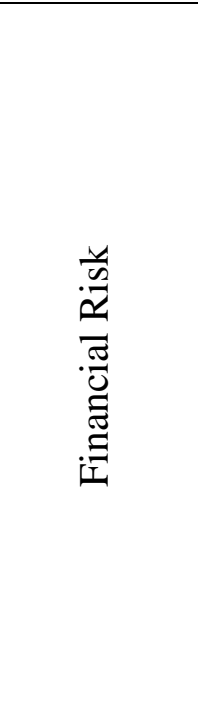 } & FINR_20 & $\begin{array}{l}\text { I am afraid of quality of financial } \\
\text { transaction system of online } \\
\text { trading. }\end{array}$ & 3.71 & 0.724 & 0.718 \\
\hline & FINR_21 & $\begin{array}{l}\text { Sellers may not execute the order } \\
\text { although buyers have paid. }\end{array}$ & 2.72 & 0.645 & 0.691 \\
\hline & FINR_22 & $\begin{array}{l}\text { Information of individual account } \\
\text { may be disclosed. }\end{array}$ & 3.61 & 0.664 & 0.760 \\
\hline & FINR_23 & $\begin{array}{l}\text { Information of payment card of } \\
\text { buyer may be disclosed. }\end{array}$ & 3.28 & 0.538 & 0.745 \\
\hline & FINR_24 & $\begin{array}{l}\text { Payment may not be returned if } \\
\text { the product is not similar to what } \\
\text { described. }\end{array}$ & 3.85 & 0.985 & 0.725 \\
\hline & \multicolumn{5}{|c|}{ Cronbach's Alpha: $0.771 \quad$ Overall means: 3.434} \\
\hline \multirow{6}{*}{ 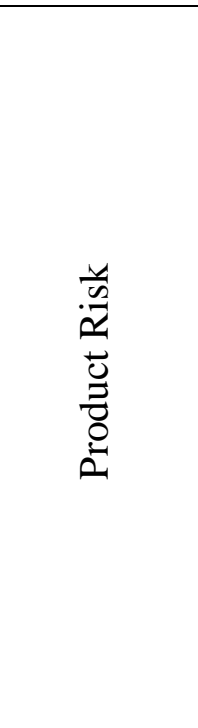 } & PROR_25 & $\begin{array}{l}\text { The size of apparel may not tally } \\
\text { with international standards. }\end{array}$ & 3.25 & 0.700 & 0.674 \\
\hline & PROR_26 & $\begin{array}{l}\text { I cannot try on the apparel } \\
\text { online. }\end{array}$ & 3.42 & 0.754 & 0.665 \\
\hline & PROR_27 & $\begin{array}{l}\text { I cannot touch and feel the } \\
\text { apparel. }\end{array}$ & 3.73 & 0.637 & 0.685 \\
\hline & PROR_28 & $\begin{array}{l}\text { I cannot receive the apparel } \\
\text { online in a few minutes. }\end{array}$ & 3.49 & 0.735 & 0.688 \\
\hline & PROR_29 & $\begin{array}{l}\text { When receiving apparel, product } \\
\text { will not be similar to the apparel } \\
\text { image I saw. }\end{array}$ & 3.31 & 0.701 & 0.648 \\
\hline & \multicolumn{5}{|c|}{ Cronbach's Alpha: $0.720 \quad$ Overall mean: 3.442} \\
\hline \multirow{2}{*}{ 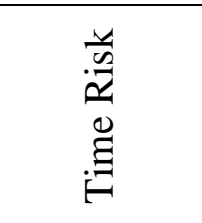 } & TIMR_30 & $\begin{array}{l}\text { Spending a lot of time learning } \\
\text { how to order apparel online. }\end{array}$ & 3.08 & 0.796 & 0.742 \\
\hline & TIMR_31 & $\begin{array}{l}\text { Spending a lot of time searching } \\
\text { the right products. }\end{array}$ & 3.18 & 0.728 & 0.753 \\
\hline
\end{tabular}




\begin{tabular}{|c|c|c|c|c|c|}
\hline Dimension & Code Item & Item Statement & Mean & $\begin{array}{l}\text { Std. } \\
\text { Deviation }\end{array}$ & $\begin{array}{l}\text { Cronbach's } \\
\text { Alpha if } \\
\text { deleted item }\end{array}$ \\
\hline & TIMR_32 & $\begin{array}{l}\text { It takes too long for the product } \\
\text { to be delivered. }\end{array}$ & 3.64 & 0.810 & 0.755 \\
\hline & TIMR_33 & $\begin{array}{l}\text { It takes too long to cancel an } \\
\text { order. }\end{array}$ & 3.15 & 0.785 & 0.771 \\
\hline & TIMR_34 & $\begin{array}{l}\text { It takes too long to complete the } \\
\text { procedures for returning a } \\
\text { product. }\end{array}$ & 3.44 & 0.747 & 0.755 \\
\hline & TIMR_35 & $\begin{array}{l}\text { It takes too long to compare prices } \\
\text { when shopping apparel online. }\end{array}$ & 3.07 & 0.816 & 0.759 \\
\hline & \multicolumn{5}{|c|}{ Cronbach's Alpha: 0.788 Overall mean: 3.261} \\
\hline \multirow{5}{*}{ 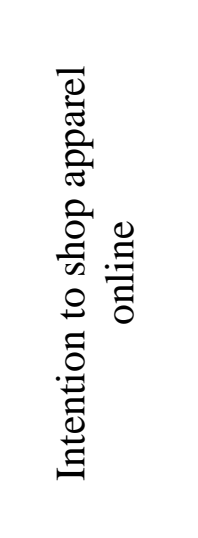 } & INTD_36 & I like to shop apparel online. & 2.95 & 0.439 & 0.694 \\
\hline & INTD_37 & $\begin{array}{l}\text { I will purchase apparel in online } \\
\text { stores more often than in } \\
\text { traditional stores. }\end{array}$ & 3.33 & 0.476 & 0.580 \\
\hline & INTD_38 & $\begin{array}{l}\text { I will purchase apparel via the } \\
\text { Internet in the near future. }\end{array}$ & 3.15 & 0.427 & 0.603 \\
\hline & INTD_39 & $\begin{array}{l}\text { I will learn how to purchase } \\
\text { apparel online in the near future. }\end{array}$ & 3.19 & 0.495 & 0.578 \\
\hline & \multicolumn{5}{|c|}{ Cronbach's Alpha: $0.683 \quad$ Overall mean: 3.156} \\
\hline
\end{tabular}

\section{Exploratory factor analysis}

An exploratory factor analysis (EFA) is performed to evaluate the validity of the measurement scales of all variables included in the proposed model. Total 36 items are entered to analyze exploratory factor and include two parts. Part 1 consists of 32 items to present perceived benefits and risks in online shopping, and part 2 with 4 items describes white collar women's intention to shop apparel online. The KMO of dimensions of perceived risks in part 1 is 0.808 , and its Barlett's test p-value is 0.000 . The KMO of intention to shop apparel online in part 2 is 0.700 , and its Barlett's test p-value is 0.000 . The test values indicate that the data are accepted to perform further factor analysis.

Then in part 1, we use principal component analysis method and variable maximization rotation to maintain 32 items. Their factor loadings are shown in Table 4. The table shows eight common factors extracted from the remaining 32 items. Cumulative extraction sum of squared loading is $57.111 \%$. All factor loadings are above 0.5 and no-cross construct loadings are above 0.3 , indicating good validity of discrimination. These eight variables can be used for multiple regression tests. In part 2 , we also get one common factor and the cumulative extraction sums of squared loading are $51.571 \%$ as shown in Table 4. 


\section{Table 4}

Factor analysis

\begin{tabular}{|c|c|c|c|}
\hline Variable & Item Code & Factor loading & $\begin{array}{c}\text { Cumulative } \\
\text { extraction } \\
\text { sums of } \\
\text { squared } \\
\text { loading }\end{array}$ \\
\hline \multirow[t]{6}{*}{ Time risk } & TIMR_31 & 0.727 & \multirow[t]{6}{*}{$17.253 \%$} \\
\hline & TIMR_32 & 0.590 & \\
\hline & TIMR_33 & 0.667 & \\
\hline & TIMR_34 & 0.581 & \\
\hline & TIMR_35 & 0.657 & \\
\hline & TIMR_36 & 0.609 & \\
\hline \multirow{5}{*}{$\begin{array}{l}\text { Financial } \\
\text { Risk }\end{array}$} & FINR_21 & 0.675 & \multirow[t]{5}{*}{$13.123 \%$} \\
\hline & FINR_22 & 0.763 & \\
\hline & FINR_23 & 0.534 & \\
\hline & FINR_24 & 0.703 & \\
\hline & FINR_25 & 0.727 & \\
\hline \multirow[t]{5}{*}{ Product Risk } & PROR_26 & 0.561 & \multirow[t]{5}{*}{$5.779 \%$} \\
\hline & PROR_27 & 0.611 & \\
\hline & PROR_28 & 0.556 & \\
\hline & PROR_29 & 0.697 & \\
\hline & PROR_30 & 0.698 & \\
\hline \multirow{3}{*}{$\begin{array}{l}\text { Abundance } \\
\text { and liking } \\
\text { Product }\end{array}$} & PROD_06 & 0.703 & \multirow[t]{3}{*}{$4.857 \%$} \\
\hline & PROD_07 & 0.791 & \\
\hline & PROD_08 & 0.756 & \\
\hline \multirow[t]{3}{*}{ Enjoyment } & ENJY_18 & 0.725 & \multirow[t]{3}{*}{$4.451 \%$} \\
\hline & ENJY_19 & 0.679 & \\
\hline & ENJY_20 & 0.620 & \\
\hline \multirow{3}{*}{$\begin{array}{l}\text { Competitive } \\
\text { Price }\end{array}$} & PRIC _10 & 0.785 & \multirow[t]{3}{*}{$4.112 \%$} \\
\hline & PRIC _11 & 0.705 & \\
\hline & PRIC_12 & 0.750 & \\
\hline \multirow{4}{*}{$\begin{array}{l}\text { Convenience } \\
\text { Shopping }\end{array}$} & CONV_01 & 0.639 & \multirow[t]{4}{*}{$3.956 \%$} \\
\hline & CONV_02 & 0.641 & \\
\hline & CONV_03 & 0.670 & \\
\hline & CONV_04 & 0.698 & \\
\hline
\end{tabular}




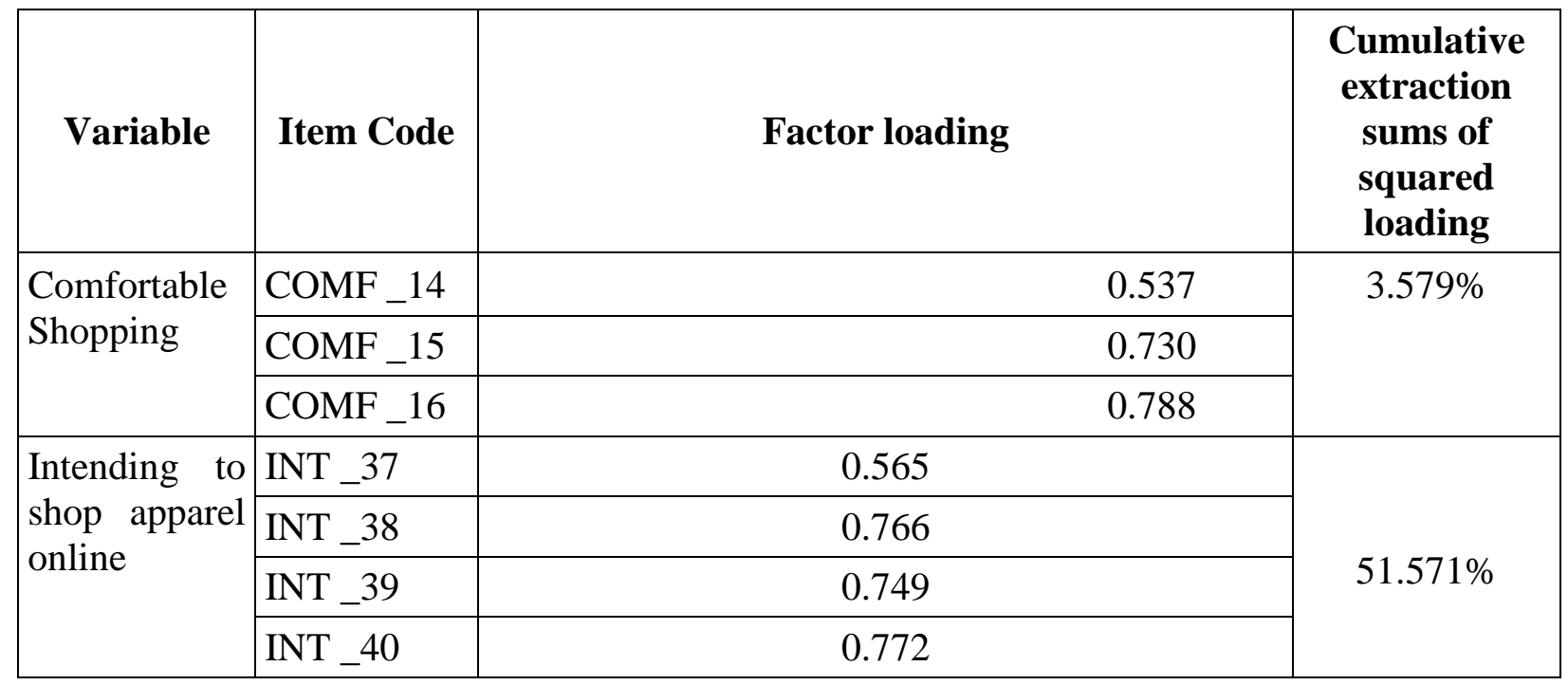

\section{Linear regression analysis}

In Table 5, five factors belonging to perceived benefits have standardized beta coefficients greater than zero with their significance less than 0.01 . This means these factors have positively affected on intention to shop apparel online so an increase of these perceived benefits will help enhance intention to shop apparel online.

On the contrary, three standardized beta coefficients of perceived risks are less than zero with their significance less than 0.01 . These factors have affected the dependent variable negatively. This means the more these three perceived risks increase, the less intention to shop apparel online decreases.

The VIF of each independent variable in the regression model is lower than 2 , which meets the criteria of multicollinearity testing (Hair et al., 2010). In other words, there is no multicollinearity in the regression model.

Table 5

Linear regression

\begin{tabular}{|l|c|c|c|}
\hline \multicolumn{1}{|c|}{ Independent Variable } & $\begin{array}{c}\text { Standardized Beta } \\
\text { Coefficients }\end{array}$ & Sig. & VIF \\
\hline Convenience shopping & 0.234 & 0.000 & 1.309 \\
\hline Abundance and diversify of product & 0.225 & 0.000 & 1.244 \\
\hline Competitive price & 0.151 & 0.000 & 1.275 \\
\hline Comfortable shopping & 0.270 & 0.000 & 1.205 \\
\hline Enjoyment & 0.157 & 0.000 & 1.310 \\
\hline Financial risk & -0.208 & 0.000 & 1.483 \\
\hline Product risk & -0.263 & 0.000 & 1.572 \\
\hline Time risk & -0.182 & 0.000 & 1.727 \\
\hline Adjusted R Square $=0.770$ & & & \\
\hline Sig. F $=0.000$ & & & \\
\hline Durbin Watson $=2.114$ & & & \\
\hline
\end{tabular}


The adjusted $\mathrm{R}$ square in the regression model is 0.770 , which means that $77 \%$ variation of white collar women's intention to shop apparel online is explained by variation of 8 factors: convenience shopping, abundance and diversify of products, competitive price, enjoyment, comfortable shopping, financial risk, product risk and time risk.

For perceived benefits, comfortable shopping has the strongest effect on online shopping intention $(\beta=0.270)$ followed by convenience shopping $(\beta=0.234)$, abundance and liking of products $(\beta=0.225)$, and enjoyment $(\beta=0.157)$ and competitive price $(\beta$ $=0.151)$. For perceived risks, product risk has the highest effect $(\beta=-0.263)$, followed by financial risk $(\beta=-0.208)$, and time risk $(\beta=$ 0.182). Thus, eight hypotheses are accepted.

\section{ANOVA test of different age groups}

This study continues exploring difference among age groups of white-collar female and their intention to shop apparel online. Whitecollar female's ages are divided into three groups: 22-30, 31-40, 41-50. The result of ANOVA test is showed in Table 6.

\section{Table 6}

Result of one-way ANOVA analysis

\begin{tabular}{|c|c|c|c|c|c|}
\hline (I) & $(\mathbf{J})$ & $\mathbf{N}$ & Means & $\begin{array}{c}\text { Mean Difference } \\
(\mathbf{I}-\mathbf{J})\end{array}$ & Sig. \\
\hline $22-30$ & $31-40$ & 98 & 3.1327 & $-0,2008^{*}$ & 0,035 \\
& $41-50$ & & & 0,1053 & 0,126 \\
\hline $31-40$ & $22-30$ & 136 & 3.3335 & $0,2008^{*}$ & 0,035 \\
& $41-50$ & & & $0,3062^{*}$ & 0,000 \\
\hline $41-50$ & $22-30$ & 64 & 3.0273 & $-0,1053$ & 0,126 \\
& $31-40$ & & & $-0,3062^{*}$ & 0,000 \\
\hline
\end{tabular}

Ages of respondents really affect their intentions. The intention of women in 31- 40 age group is significantly different from that of women in 41- 50 age group and women in 22- 30 age group. The greatest intention belongs to women of 31-40 age group (mean $=3.33$ ), followed by 22-30 age group (mean $=3.13$ ), and 41-50 age group (mean =3.03).

In brief, all eight hypotheses are supported, of which 5 hypotheses shows the positive correlation between perceived benefits and shopping intention and 3 hypotheses show the negative correlation between perceived risks and shopping intention. The degree effect of each benefit and risk on white collar women's intention to shop apparel online is different. The age group of 31-40 has strongest intention to buy apparel online.

\section{Conclusion and future directions \\ Conclusion}

This study determines that there are five dimensions of white-collar women's perceived benefits and three dimensions of their perceived risks when they consider shopping apparel online. All eight dimensions give good explanations about the benefits and risks when shopping online. Perceived benefits have positive influence, on the contrary, perceived risks have negative influence on white collar women's intention to shop apparel online. Managers should concentrate on enhancing the benefits and reducing the risks to redouble competitive capacity of their websites and attract more customers, especially the main market segment of white-collar women from 31 to 40 
years of age.

Managers should improve selling process to make it easier and more convenient for customers. Furthermore, they need to advertise their websites widely to help customers recognize the convenience of shopping online.

To enhance white-collar women to shop apparel online, managers should pay attention to product's factors by diversifying product styles. More focus should be put on fashionable tendency by designing attractive interface with understandable navigation to make customers comfortable and save time in their search for favorite items. Website design should be friendly to help consumers stay longer in the site and get more shopping experience. Information about product characteristics and related services should be continuously updated and truthful to build customer's trust of e-retailer.

Online price of apparel should be lower than that of physical stores to attract more women to purchase apparel online. Women often consider product's price before purchasing. They also tend to compare prices among known brands so competitive price is a key to attract white-collar women to do more shopping. Return policy, i.e. allowing customers return apparel in suitable time, and guiding them to physical place to try out and select the most suitable one, will contribute to establish website's reliability. Addition to applying modern payment methods like credit cards, debit cards, and e-wallet, managers should maintain COD delivery system because the white-collar women want to touch apparel before they pay. Hotline and chat room of customer services should be operated effectively to relieve consumers' perceived risks.

\section{Future direction}

Our study provides a new measurement of perceived benefits and risks dimensions which influence on the intent to shopping apparel online of Vietnamese white-collar women. This study sets some foundation for further research on online shopping intention with other investigated objects and other online products because specific products and objects will have different perceived benefits and risks.

At the same time, a future additional proposition of our study lies at considering a correlation between consumers' purchasable intention and real purchasing behavior. Moreover, future studies can perform larger sample size and choose appropriate sampling to gain higher generalizability

\section{References}

Azura, Z. (2010). The Influence of the Intention Online Purchase Among University Kuala Lumpur, Malaysian Institute of Information Technology Lecturer's and Staff's. Unpublished Final Year Project, Malaysian Institute of Information Technology, University of Kuala Lumpur, Malaysia.

Alreck, P. and Settle, R. (2002). The hurried consumer: time-saving perceptions of internet and catalogue shopping. Journal of Database Marketing, 10(1), 25-35.

Barnes, S.J., Bauer, H.H., Neumann, M.M. and Huber, F. (2007). Segmenting cyberspace: a customer typology for the Internet. European Journal of Marketing, 41(1/2), 71-93.

Chan, I.W., Ling, L.H, Ying L.H., Hiang, T.S. and Kuan, T.S. (2012). Relationship between perceived benefits and undergraduates' online shopping decisions in Malaysia, Universiti Tunku Abdul Rahman.

Crespo A.H., Bosque, I.E. and Sánchez, M.G.S. (2009). The influence of perceived risk on Internet shopping behavior: a multidimensional perspective. Journal of Risk Research, 12(2), 259-277.

Delafrooz and Narges (2009). Factors Affecting Students' Online Shopping Attitude and Purchase Intention, PhD thesis, Universiti Putra Malaysia. [Online]. Available: http://psasir.upm.edu.my/5673/1/FEM_2009_3.pdf [2013, July 20]. 
Forsythe, S., Liu, C., Shannon, D. and Gardner L.C. (2006). Development of a scale to measure the perceived benefits and risks of online shopping. Journal of Interactive Marketing, 20(2), 55-75.

Hair, J.F., Black, W.C., Babin, B.J., \& Anderson, R.E. (2010). Multivariate Data Analysis. Seventh Edition. Prentice Hall, Upper Saddle River, New Jersey.

Hoffman, D., Novak, T., and Peralta, M. (1999). Building consumer trust online. Commun. ACM, 42(4), 80-85.

Javadi, M.H.M., Dolatabadi, H. R., Nourbakhsh, M., Poursaeedi, A. and Asadollahi, A. R. (2012). An Analysis of Factors Affecting on Online Shopping Behavior of Consumers. International Journal of Marketing Studies, 4(5), 81-98.

Lim, W.M and Ting, D.H. (2012). E-shopping: an Analysis of the Technology Acceptance Model. Modern Applied Science, 6(4), 24-50.

Martin, S. and Camarero, C. (2009). How perceived risk affects online buying. Online Information Review, 33(4), 629-654.

Nguyen Thi Bao Chau and Le Nguyen Xuan Dao (2013). Phân tích các nhân tố ảnh hưởng đến hành vi mua sắm trực tuyến của người tiêu dùng thành phố Cần Thơ. Tạp chí khoa học truờng Đại học Cần Tho, phần D: Khoa học Chính trị , Kinh tế và Pháp luật: 30.

Oxford (1989). Oxford English Dictionary. Oxford University Press, $2^{\text {nd }}$ edition.

Thesaigontimes (2015). Mastercard: mua sắm trực tuyến ở Việt Nam tăng nhanh thứ hai Châu Á-Thái Bình Dương. < http://www.thesaigontimes.vn/126967/Mastercard-mua-sam-truc-tuyen-o-VN-tang-nhanh-thu-hai-chau-ATBD.html>, accessed June 28, 2015.

Vecita (2015). Báo cáo thương mại điện tử Việt Nam năm 2014. <http:// www.vecita.gov.vn/anpham/230/Bao-caoThuong-mai-dien-tu-Viet-Nam-nam-2014>, ngày truy cập 20/03/2015.

Wani, S.N. and Malik, S. (2013). A Comparative Study of Online Shopping Behaviour: Effects of Perceived Risks and Benefits. International Journal of Marketing and Business Communication. 